\title{
Seroprevalence of transfusion transmissible viral infections (HIV, HBV and HCV) among voluntary blood donors at University of Gondar Comprehensive Specialized Hospital, Gondar; Northwest Ethiopia
}

Abiye Tigabu ${ }^{1 *}$, Tigist Engda ${ }^{1}$ and Feleke Mekonnen ${ }^{2}$

\begin{abstract}
Background: Human immunodeficiency virus, hepatitis B virus and hepatitis C virus are among the greatest threats to blood safety for the recipient. They are also the leading cause of death, chronic and life-threatening abnormalities. Therefore, this study was aimed to assess the Sero-prevalence of HIV, Hepatitis B and C virus among blood donors at the University of Gondar Comprehensive Specialized Hospital.

Methods: A retrospective cross-sectional study was used to estimate the seroprevalence of HIV, Hepatitis B and C virus among blood donors at the University of Gondar Comprehensive Specialized Hospital from May-July 2018. Screening of HIV, HBV, and HCV was done by using the Enzyme-Linked ImmunoSorbent Assay. Records of 5983 first time blood donors were collected and reviewed by using a checklist from registration book. Data was entered in statistical package EP Info version 3.5.1, and data cleaned and analyzed using the statistical package SPSS version 16.0.

Results: Of 5983 blood donors, 85.5\% (5118/5983) donors were males and 14.5\% (865/5983) were females. The median age was 27 years and the highest blood donations age category was between 20 to 51.2\% (29/5983) followed by 30 to 39 years of age, 21.6\% (1295/5983). The prevalence of HIV, HBV and HCV infections were 2.5\% (95\% Cl: 1.07-2.398), 4.1\% (95\% Cl: $0.461-1.053)$ and 1.6\% (95\% Cl: 0.845-3.354), respectively. HIV infection was significantly associated with gender $\left(p=0.021, x^{2}=5.358\right)$ and HCV infection with age group $\left(p=0.003, x^{2}=17.673\right)$. Of all donated blood, 8.2\% (489/5983) had serological evidence for at least one of the screened pathogens and 58 (0.96\%) of them had multiple infections.

Conclusions: This study showed a significant prevalence of HIV, HBV, and HCV among blood donors, 2.5\% (147/5983), 4.1\% (244/5983) and 1.6\% (98/5983), respectively. Therefore, strict selection of blood donors with an emphasis on getting voluntary blood donors, and highly sensitive and specific tests for screening of blood donors for HIV, HBV, and HCV using standard methods are highly recommended to ensure the safety of blood for the recipient.
\end{abstract}

Keywords: Seroprevalence, Transfusion-transmissible viral infections, HIV, HBV, HCV, Blood donors

\footnotetext{
* Correspondence: abty12@gmail.com

${ }^{1}$ Department of Medical Microbiology, School of Biomedical and Laboratory

Sciences, College of Medicine and Health Sciences, University of Gondar, P

O.box: 196, Gondar, Ethiopia

Full list of author information is available at the end of the article
}

(c) The Author(s). 2019 Open Access This article is distributed under the terms of the Creative Commons Attribution 4.0 International License (http://creativecommons.org/licenses/by/4.0/), which permits unrestricted use, distribution, and reproduction in any medium, provided you give appropriate credit to the original author(s) and the source, provide a link to the Creative Commons license, and indicate if changes were made. The Creative Commons Public Domain Dedication waiver (http://creativecommons.org/publicdomain/zero/1.0/) applies to the data made available in this article, unless otherwise stated. 


\section{Background}

Human immunodeficiency virus (HIV), hepatitis B virus (HBV) and hepatitis $\mathrm{C}$ virus $(\mathrm{HCV})$ are the greatest threats to blood safety because of their prolonged presence in the blood as a carrier or latent state. They are the leading cause of death, chronic and life-threatening abnormality. Blood transfusion accounts for $5-10 \%$ of HIV infections in sub-Saharan Africa [1]. The frequency of HIV infection among blood donors varies significantly between different countries of the world. There is a strong association between infection with the human immunodeficiency virus and hepatitis $C$ virus infection [2]. HIV infection occurs worldwide and is endemic in central Africa. Transmission occurs through sexual contact, exposure to contaminated blood or blood products, and perennially. Human immunodeficiency virus is one member of the human retrovirus and is associated with progressive immune deficiency accompanied by a wide range of opportunistic infections [3].

Hepatitis B virus (HBV) is generally recognized as highly infectious and associated with long term occurrence of disease and death due to complications like cirrhosis, portal hypertension, and Hepato-cellular carcinoma. Approximately greater than 2 billion people have been infected by $\mathrm{HBV}$ and 350 million individual people have chronic infection [1, 4]. The common high-risk groups for HBV infections are parenteral drug abusers, institutionalized persons, health care personnel, multiply transfused patients, organ transplant patients, hemodialysis patients, highly promiscuous persons, sexual transmission and newborn infants born to mothers with hepatitis B virus [5]. The virus is highly infectious and relatively easy to be transmitted from one infected person to another by blood to blood contact, during birth, unprotected sex, and by sharing needles and has a relatively increase the prevalence in the tropics [6].

Hepatitis C virus (HCV) was identified in 1989 as the major agent of post-transfusion hepatitis previously designated under the name of "non-A, non-B hepatitis [7]. It is a blood-borne pathogen transmitted most efficiently by percutaneous membrane exposure to contagious blood. It is estimated that $60 \%$ of hepatitis $C$ cases are related to injection drug use (IDU) [8]. HCV infection is highly recognized as a major healthcare problem throughout the world and around 130 to 170 million people are chronic carriers of this virus in the world, with an average seroprevalence estimated at $2.2 \%$. This rate varies from country to country: it is very low in Europe, higher in Southeast Asia and Africa [7]. HCV causes $85 \%$ persistent infection, of this $70 \%$ of them develops chronic hepatitis, resulting in cirrhosis of the liver within 20 years and hepatocellular carcinoma (HCC) in a further 10 years [9]. Hepatitis $C$ virus is associated with the seropositivity of the human immunodeficiency virus infection [2].
There are some reports which indicate the burden of transfusion-transmissible viral infections in Ethiopia. However, there are several localities including the current study area in which prevalence and trends yet not determined. Therefore, this study was aimed to determine the seroprevalence of HIV, Hepatitis B and C virus among blood donors at the University of Gondar Comprehensive Specialized Hospital., Gondar, Ethiopia.

\section{Methods}

Study design, study area, data collection

A retrospective cross-sectional study was conducted to determine the seroprevalence of HIV, Hepatitis B and C virus among first time voluntary blood donors at the University of Gondar compressive specialized Hospital from May-July 2018. Records of 5983 blood donors were collected and reviewed by using a checklist from registration book at blood banking unit of the hospital. Information concerning HIV, HBV and HCV test results, age, sex and occupation of blood donors recorded from September 2014-September 2017 in the registration book was collected using a data collection format.

\section{Laboratory detection methods}

Screening for HIV, HBV and HCV was done by using the Enzyme-Linked ImmunoSorbent Assay (ELISA) (HIV1/2: Vironostika HIV Uni-Form II Ag/Ab fourth generation ELISA, Bio-Merieux, Boxtel, Netherlands; HBsAg: a third generation ELISA, Hepanostika HBsAg UNi-Form II, Bio-Merieux, Boxtel, Netherlands; HCV: Human anti$\mathrm{HCV}$ third generation ELISA, HumanGasellschaft for Biochemical and diagnostic $\mathrm{MbH}$, Germany). Test protocol and result interpretation were done according to the manufacturer instruction.

\section{Data management and statistical analysis}

Quantitative data was entered in statistical package EP-Info version 3.5.1, and data cleaned and analyzed using the statistical package SPSS version 16.0. Frequency distribution, percentages and summary statistics were used to describe the study population in relation to relevant variables. Odds Ratio (OR) was computed to assess statistical association, and the significance of statistical association was assured using $p$-value $<0.05$ at $95 \%$ confidence interval (CI).

\section{Results}

\section{Socio-demographic characteristics of blood donors}

A total of 5983 consecutive first time blood donors were screened at University of Gondar Teaching Hospital blood bank unit during the study period. Of these, 5118 (85.5\%) donors were males and 865 (14.5\%) were females. The median age of these blood donors was 27 years (range 1568 years) and the highest blood donations age category 
was between 20 to 29 (51.2\%), followed by 30 to 39 years of age $(21.6 \%)$ (Table 1$)$.

\section{Seroprevalence of HIV, HBV, and HCV}

The overall prevalence rates of HIV, HBV, and HCV were $2.5 \%$ (147/5983), 4.1\% (244/5983) and 1.6\% (98/5983), respectively. Of all donated blood during the study period, $8.2 \%(489 / 5983)$ had serological evidence for at least one of the screened pathogens, and $0.97 \%(58 / 5983)$ of them was multiple infections. Of these, $88.2 \%(431 / 489)$ and $11.8 \%(58 / 489)$ had single and multiple infections, respectively. Among those with multiple infections, the most common combination was HIV-HBV 50\% (29/58), then followed by HBV-HCV 25.9\% (15/58), HIV-HCV 24.1\% $(14 / 58)$ and HIV-HBV-HCV 8.6\% (5/58). The seroprevalence of HIV in male and female donors is $1.94 \%$ (116/ $5983)$ and $0.52 \%(31 / 5983)$, respectively. The difference is statistically significant $(p=0.021)$. HIV prevalence rate among age category $<20,20$ to 29,30 to 39,40 to 49,50 to 59 and 60 \& above was $0.2 \%$ (12/5983), $1.1 \%(66 / 5983)$, $0.74 \%$ (44/5983), $0.25 \%$ (15/5983), $0.15 \%$ (9/5983) and $0.02 \%$ (1/5983), respectively. Age with different category does not have a statistically significant association with HIV $(p=2.51)$ (Table 2).

The seroprevalence of HBV was higher among males, $3.64 \%(218 / 5983)$ compared to females, $0.43 \%$ (26/5983) but the difference is not statistically significant $(p=0.085)$. Its prevalence among age category $<20,20$ to 29,30 to 39 , 40 to 49,50 to 59 and 60 \& above was $0.32 \%(19 / 5983)$, $1.9 \%$ (113/5983), $0.9 \%$ (54/5983), $0.7 \%$ (41/5983), $0.27 \%$ $(16 / 5983)$ and $0.02 \%(1 / 5983)$, respectively. Age with different category do not have statistically significant association with HBV $(p=0.319)$ (Table 3$)$. Similarly, the seroprevalence of HCV in male was 1.5\% (89/5983) compared to females $0.15 \%$ (9/5983). The difference is not

Table 1 Frequency of blood donors by age groups and gender at University of Gondar Compressive Specialized Hospital, North West Ethiopia, 2018

\begin{tabular}{lll}
\hline Characteristics & Frequency $(\mathrm{No})$ & Percent $(\%)$ \\
\hline Age group (years) & & \\
$<20$ & 509 & 8.5 \\
$20-29$ & 3063 & 51.2 \\
$30-39$ & 1295 & 21.6 \\
$40-49$ & 740 & 12.4 \\
$50-59$ & 341 & 5.7 \\
$60 \&$ above & 35 & 0.6 \\
Total & 5983 & 100.0 \\
Gender & & \\
Male & 5118 & 85.5 \\
Female & 865 & 14.5 \\
Total & 5983 & 100.0 \\
\hline
\end{tabular}

statistically significant $(p=0.134)$. Its seroprevalence of HCV with age group, <20, 20 to 29,30 to 39,40 to 49,50 to 59 and 60 \& above was $0.03 \%$ (2/5983), $0.7 \%(42 / 5983)$, $0.55 \%$ (33/5983), $0.25 \%$ (15/5983), $0.07 \%$ (4/5983) and $0.03 \%(2 / 5983)$, respectively. The difference is statistically significant $(p=0.003)$ (Table 4$)$. HBV is the most important infection especially in male, $3.64 \%$ to compare with female, $0.43 \%$. And HIV is contributing higher percentage in male, $1.94 \%$ to compare with female, $0.52 \%$. Similarly, $\mathrm{HCV}$ is slightly higher in male, $1.5 \%$ to compare with female, $0.15 \%$ but it was lower than the total infection of HIV and HVB infection (Fig. 1).

\section{Trends of HIV, HBV and HCV Seroprevalence}

Over the three years study periods, the seroprevalence of HIV was decreased from 3.3\% in September 2014-August 2015 to 2.6\% in September 2015-August 2016 and $1.7 \%$ in September 2016-August 2017. Similarly, the prevalence of $\mathrm{HBV}$ decreased progressively from $5.2 \%$ in September 2014-August 2015 to 4.0\% in September 2015 -August 2016 and 3.1\% in September 2016 - August 2017. However, the seroprevalence of HCV was increased from 1.4\% in September 2014-August 2015 to 2.3\% in September 2015 - August 2016 but slightly decreased 1.3\% in September 2016 - August 2017 (Fig. 2).

\section{Discussion}

One of the main recommendations of the WHO to achieve a safe and sufficient blood supply is the collection of blood from voluntary regular non-remunerated donors who have a lower risk of TTIs compared to family replacement and commercial donors. In this study, the overall prevalence of HIV among blood donors in the last three years at University of Gondar compressive specialized Hospital blood bank, $2.5 \%$ is lower than previous studies conducted Ethiopia, 3.8 and $11.79 \%$ [16, 25], in Cameroon, 2.9 and 4.1\% [12, 23], in Dares salaam, 3.8\% [13], in Mozambique, 8.5\% [24], in Nigeria, 2.8, 6.2 and $3.1 \%$ [17, 26, 27]. However, the overall prevalence of HIV in this study, $2.5 \%$ was higher as compared to the prevalence of HIV in Ethiopia, 1.4, 0.25 and 0.1\% [18, 37, 39], in Netherland, $0.06 \%$ [10], in Nepal, 0.12\% [11], in the University Clinics of Kinshasa of Democratic Republic of the Congo, 2.2\% [2], in Saudi Arabia, 0\% [14], in Istanbul, Turkey, 0.008\% [28], in Kathmandu, Nepal, 0.007\% [29], in Pakistan, 0.007, 0.25, 0.017 and 0.09\% [30, 35, 38, 40], in Delhi, 0.56\% [31], in Kashan, Iran, 0\% [32], in southeastern Anatolia, 0.0004\% [33], in India, 0.27 and 0.39\% [34, 42], in Koudougou, 2.21\% [36], in Lahore, 0.05\% [41]. This variation of seroprevalence of TTIs from other studies might be due to due to difference in the characteristics of the study population, geographical distribution and diagnostic techniques. 
Table 2 Seroprevalence of HIV among different age and gender categories at University of Gondar Compressive Specialized Hospital in Northwest Ethiopia, 2018

\begin{tabular}{|c|c|c|c|c|c|c|}
\hline \multirow[t]{2}{*}{ Variable } & \multicolumn{2}{|l|}{ HIV status } & \multirow{2}{*}{$\begin{array}{l}\text { Chi- } \\
\text { square }\end{array}$} & \multirow{2}{*}{$\begin{array}{l}\text { Crude } \\
\text { OR }\end{array}$} & \multirow[t]{2}{*}{$\mathrm{Cl}$} & \multirow[t]{2}{*}{$P$-value } \\
\hline & Negative (\%) & Positive (\%) & & & & \\
\hline \multicolumn{7}{|l|}{ Gender } \\
\hline Male & 5002 (83.6\%) & 116 (1.94\%) & 5.264 & 1.6 & $1.07-2.398$ & 0.022 \\
\hline Female & $834(13.9 \%)$ & 31 (0.52\%) & - & - & - & - \\
\hline \multicolumn{7}{|l|}{ Age category } \\
\hline$<20$ & 497 (8.3\%) & $12(0.2 \%)$ & 6.504 & - & - & 0.260 \\
\hline $20-29$ & 2997 (50\%) & 66 (1.1\%) & 0.84 & 0.912 & $0.489-1.700$ & 0.772 \\
\hline $30-39$ & $1251(21 \%)$ & 44 (0.74\%) & 1.300 & 1.457 & $0.763-2.781$ & 0.254 \\
\hline $40-49$ & 725 (12.1\%) & $15(0.25 \%)$ & 0.155 & 0.857 & $0.398-1.846$ & 0.693 \\
\hline $50-59$ & $332(5.51 \%)$ & $9(0.15 \%)$ & 0.067 & 1.123 & $0.468-2.694$ & 0.795 \\
\hline 60 \& above & 34 (0.57\%) & 1 (0.02\%) & 0.035 & 1.218 & $0.154-9.647$ & 0.852 \\
\hline
\end{tabular}

Higher HIV prevalence rates were observed in the age groups of $20-29(1.1 \%)$ followed by $30-39(0.74 \%)$. The prevalence of HIV detected in the age groups of 20-29 was higher as compared to other age groups. Hence, the risk of HIV infection in age groups 20-29 is 1.5 times higher when compared with age groups less than 20 years. The higher prevalence of HIV in the age group 20-29 might be due to peoples in this age group have high-risk behaviors such as multiple sex partners, intravenous drug abuse and unprotected sexual intercourse. The seroprevalence of HIV was statistically significant among male donors, $1.94 \%(116 / 5983)$ compared to female, $0.52 \%(31 / 5983)(P=0.021)$. The higher in HIV positive male donors might be due to their increased vulnerability to HIV infection as result of biological, economic and social disadvantages.

The prevalence of HBV in this study among University of Gondar Hospital blood bank blood donors, $4.1 \%$ in line with the previous study in Pakistan, 4.0\% [30]. The prevalence of $\mathrm{HBV}$ among blood donors in the present study, $4.1 \%$ was higher when compared with studies on blood donors in Netherlands, $0.215 \%$ [10], and in Nepal, 0.46 and $0.007 \%$ [11, 29], in Saudi Arabia, 1.5\% [14], in Istanbul, Turkey, $1.76 \%$ [28], in Delhi, 2.23\% [31], in Kashan, Iran, 0.5\% [32], in southeastern Anatolia, 3.17\% [33], in India, 1.38 and 1.41\% [34, 42], in Pakistan, 2.51, 2.35 and $1.9 \%$ [35, 38, 40], in Ethiopia, 1.2\% [37], in Lahore, 1.7\% [41], and lower than a study in Ethiopia, 25 and $10.9 \%$ [25, 39], in Cameroon, 10.3 and $10.1 \%$ [12, 23], in Dares salaam, 8.8\% [13], in Mozambique, 10.6\% [24], in Nigeria, 10 and $18.6 \%$ [26, 27], in Koudougou, $14.96 \%$ [36]. The reasons for the relatively lower or higher rate of seroprevalence of HBV in this study as compared to other studies might be the improvement in diagnostic technology might make current screening reagents to be more specific and reliable; the economic status of the country and the geographical differences in prevalence.

The seroprevalence of HBV detected in the age groups of $20-29,1.9 \%(113 / 5983)$ and 30-39 years, 0.9\% (54/5983) was higher than other age groups. The risk of $\mathrm{HBV}$

Table 3 Seroprevalence of HBV among different Age and Gender categories at University of Gondar Compressive Specialized Hospital, Northwest Ethiopia. 2018

\begin{tabular}{|c|c|c|c|c|c|c|}
\hline \multirow[t]{2}{*}{ Variable } & \multicolumn{2}{|l|}{ HBV status } & \multirow{2}{*}{$\begin{array}{l}\text { Chi- } \\
\text { square }\end{array}$} & \multirow{2}{*}{$\begin{array}{l}\text { Crude } \\
\text { OR }\end{array}$} & \multirow[t]{2}{*}{$\mathrm{Cl}$} & \multirow[t]{2}{*}{$P$-value } \\
\hline & Negative (\%) & Positive (\%) & & & & \\
\hline \multicolumn{7}{|l|}{ Gender } \\
\hline Male & $4900(82 \%)$ & $218(3.64 \%)$ & 2.942 & 0.697 & $0.461-1.053$ & 0.086 \\
\hline Female & 839 (14\%) & $26(0.43 \%)$ & - & - & - & - \\
\hline \multicolumn{7}{|l|}{ Age group } \\
\hline$<20$ & 490 (8.2\%) & 19 (0.32\%) & 5.810 & - & - & 0.325 \\
\hline $20-29$ & $2950(49.3 \%)$ & 113 (1.9\%) & 0.70 & 1.318 & $0.171-10.146$ & 0.791 \\
\hline $30-39$ & $1241(20.7 \%)$ & $54(0.9 \%)$ & 0.067 & 1.302 & $0.177-9.599$ & 0.795 \\
\hline $40-49$ & 699 (11.7\%) & 41 (0.7\%) & 0.146 & 1.479 & 0.199-11.010 & 0.702 \\
\hline $50-59$ & 325 (5.4\%) & $16(0.27 \%)$ & 0.452 & 1.994 & $0.266-14.934$ & 0.502 \\
\hline 60 \& above & $34(0.57 \%)$ & $1(0.02 \%)$ & 0.242 & 1.674 & $0.215-13.014$ & 0.623 \\
\hline
\end{tabular}


Table 4 Seroprevalence of HCV among different age and gender categories at University of Gondar Compressive Specialized Hospital, Northwest Ethiopia, 2018

\begin{tabular}{|c|c|c|c|c|c|c|}
\hline \multirow[t]{2}{*}{ Variable } & \multicolumn{2}{|l|}{ HCV status } & \multirow{2}{*}{$\begin{array}{l}\text { Chi- } \\
\text { square }\end{array}$} & \multirow{2}{*}{$\begin{array}{l}\text { Crude } \\
\text { OR }\end{array}$} & \multirow[t]{2}{*}{$\mathrm{Cl}$} & \multirow[t]{2}{*}{$P$-value } \\
\hline & Negative (\%) & Positive (\%) & & & & \\
\hline \multicolumn{7}{|l|}{ Gender } \\
\hline Male & $5029(84.1 \%)$ & 89 (1.5\%) & 2.192 & 1.697 & $0.845-3.354$ & 0.139 \\
\hline Female & $856(14.3 \%)$ & $9(0.15 \%)$ & - & - & - & - \\
\hline \multicolumn{7}{|l|}{ Age category } \\
\hline$<20$ & $507(8.5 \%)$ & $2(0.03 \%)$ & 15.579 & - & - & 0.008 \\
\hline $20-29$ & 3021 (50.1\%) & $42(0.7 \%)$ & 3.016 & 3.524 & $0.850-14.604$ & 0.082 \\
\hline $30-39$ & $1262(21.1 \%)$ & $33(0.55 \%)$ & 6.711 & 6.629 & $1.585-27.727$ & 0.010 \\
\hline $40-49$ & 725 (12.1\%) & 15 (0.25\%) & 4.818 & 5.245 & $1.194-23.035$ & 0.028 \\
\hline $50-59$ & $337(5.6 \%)$ & $4(0.07 \%)$ & 1.607 & 3.009 & $0.548-16.519$ & 0.205 \\
\hline $60 \&$ above & $33(0.55 \%)$ & $2(0.03 \%)$ & 7.230 & 15.346 & $2.094-112.54$ & 0.007 \\
\hline
\end{tabular}

infection among age groups 20-29 was 1.5 times higher compared with other age groups. This study was similar to the previous reports in Kathmandu, Nepal [11], Amhara and Tigray regional states, Ethiopia [15]. HBV seroprevalence was highest in these age groups might be due to the different risk behaviors in these age groups. HBV infection by gender distribution showed that the prevalence of $\mathrm{HBV}$ among males, $3.64 \%$ was higher than the females, $0.43 \%$. A higher seroprevalence rate among male donors than the female blood donors might be due to risk behaviors of males, such as outside socialization, multiple sex relationships and may also be due to fewer females donating blood; hence fewer females are screened compared to males.

The prevalence of $\mathrm{HCV}$ in this study was $1.6 \%$ in blood donors. This study showed a similar prevalence rate with the study in Amhara and Tigray regional states, Ethiopia, 1.7\% [15], in Dares salaam, 1.5\% [13], in Abidjan Cote d'Ivoire, 1.5\% [22], in Antananarivo, Madagascar, 1.6\% [19] and in Nigeria, 1.5\% [26]. However, this study showed higher prevalence than a study in Ethiopia, 0.7, 0.32 and $0.4 \%$ [16, 37, 39], in Netherland, 0.488\% [10], Nepal, 0.64 and $0.48 \%[11,29]$, in the University Clinics of Kinshasa of Democratic Republic of the Congo, 1.3\% [9], Saudi Arabia, $0.4 \%$ [14], Istanbul, Turkey, 0.07\% [28], in Delhi, 0.66\% [31], in Kashan, Iran, 0.5\% [32], in southeastern Anatolia, $0.64 \%$ [33], in India, 0.54 and $0.84 \%$ [34, 42]. But this HCV prevalence in this study lower than a study in Ethiopia, 13.3\% [25], Cameroon, 4.8\% [23], in Pakistan, 3.3, 5.14, $3.26,2.61 \%$ [30, 35, 38, 40], in Nigeria, 6\% [27], in Koudougou, $8.69 \%$ [36] and in Lahore, 7.69\% [41]. This difference in prevalence of HCV from other studies might be due to the difference in characteristics of the study population, geographical distribution and diagnostic techniques.

The seroprevalence of $\mathrm{HCV}$ was detected in the age groups of $20-29$, and $30-39$ years was $0.7 \%(42 / 5983)$ \& $0.55 \%$ (33/5983), respectively which is higher as compared

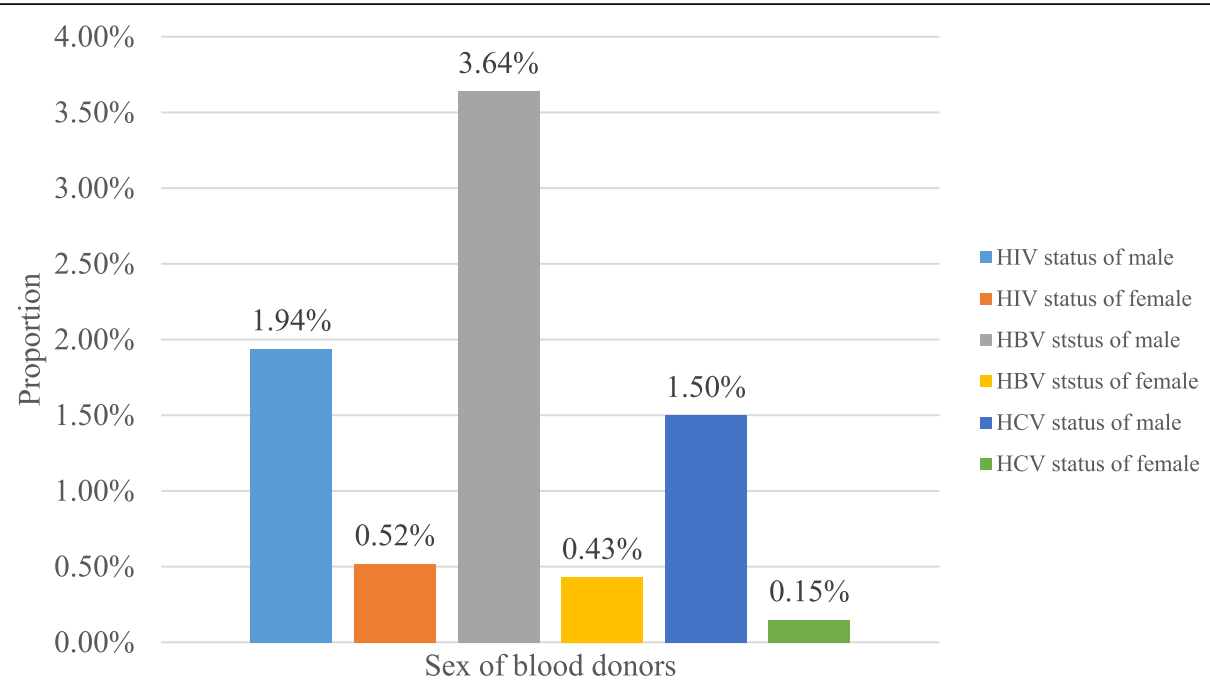

Fig. 1 Comparison of HIV, HBV and HCV among Gender at University of Gondar Compressive Specialized Hospital, Northwest Ethiopia, 2018 


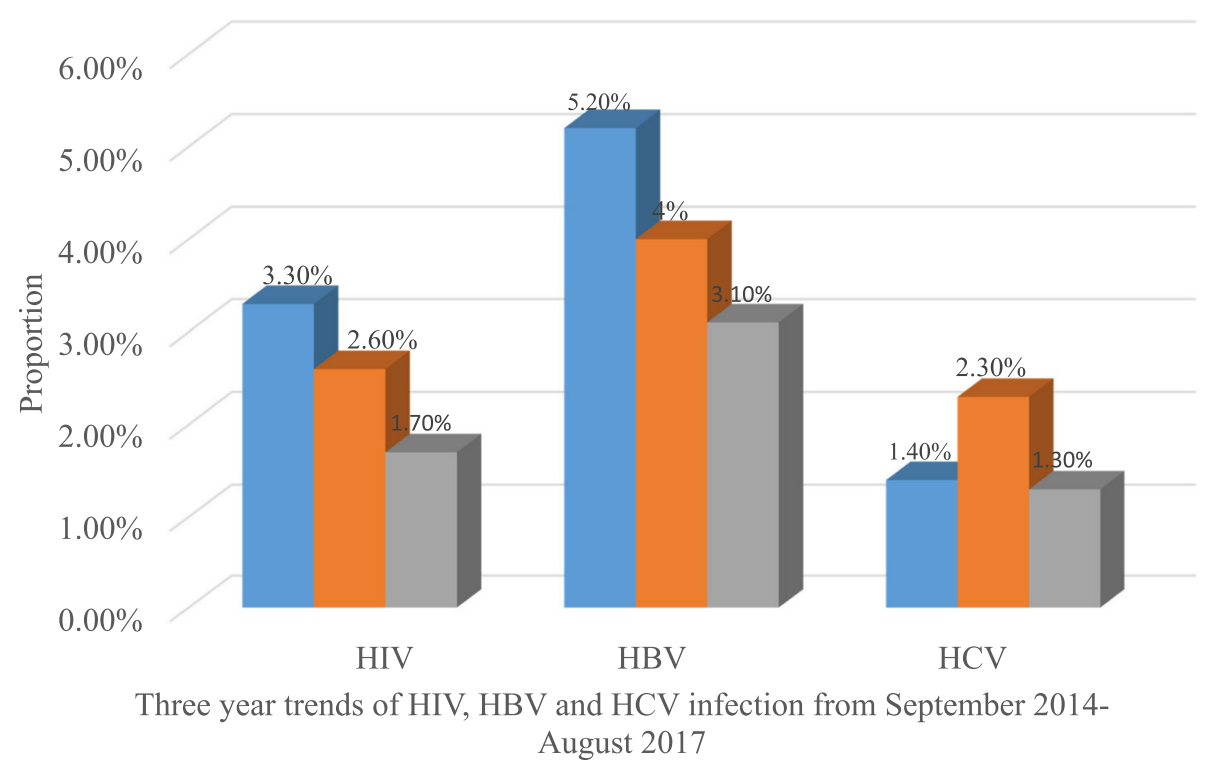

Fig. 2 Trends of HIV, HBV and HCV infection by years at University of Gondar Compressive Specialized Hospital, Northwest Ethiopia, 2018

to other age groups. The difference is statistically significant $(p=0.003)$. Which shows, the risk of HCV in the age group 20-29 increased by $93 \%$ compared with other age groups. This finding in line with other studies [20,21]. The risk of $\mathrm{HCV}$ infection in young age increment might be due to a higher habit of alcohol drinking, having multiple sexual partners and intravenous drug users among young age groups.

HCV infection by gender distribution showed that male had a $1.5 \%$ prevalence which shows higher than their female counterparts, $0.15 \%$. This finding similar to the finding of seroprevalence $\mathrm{HCV}$ among blood donors in Gondar [16] and in Madagascar [19]. High prevalence of HIV, HBV, and HCV co-infection was detected among blood donors and five cases showed the presence of three markers (HIV, HBV, and HCV). The HIV-HBV co-infection rate was $50 \%$, the HIV-HCV co-infection rate was $24 \%$, the $\mathrm{HBV}-\mathrm{HCV}$ co-infection rate was $26 \%$ and HIV-HBV- $\mathrm{HCV}$ co-infection rate was $8.6 \%$. It might be due to a similar mode of transmission, namely through sexual activity, blood and blood products, sharing of needles to inject drugs and co-infection with the impairment of the immune system.

The trends in transfusion-transmitted infections (TTIs) in blood donors tend to decrease in this study, HIV, HBV, and HCV went from 3.3, 5.2, and $1.4 \%$ in September 2014 - August 2015, 2.6, 5.2, and 2.3\% in September 2015 - August 2016 and 1.7, 4.0 and 1.3\% in September 2016 - September 2017 respectively, compared with those in the previous studies [13, 22]. But the seroprevalence of $\mathrm{HCV}$ was not constantly decreased in this study. The lower prevalence and decreasing trend TTIs in this study might be due to the increment of awareness on the prevention measures, the disease, and modes of prevention.

\section{Conclusion}

A large percentage of the blood donors harbor transfusiontransmissible infections, $8.2 \%$ with at least one screened pathogen and $0.96 \%$ with multiple infections. The prevalence of TTI infection high for all blood donors especially for age groups such as 20-29 and 30-39 years. Therefore, strict selection of blood donors with the emphasis on getting voluntary donors and highly sensitive and specific tests for screening of donors' blood for HIV, HBV, and HCV using standard methods are highly recommended to ensure the safety of blood for the recipient. The prevalence of HIV-HBV, HIV-HCV, and HBV-HCV co-infection need to be studied on a larger scale for a better understanding of the impact on clinical condition and treatment response.

\section{Abbreviations}

AIDS: Acquired Immuno Deficient Syndrome; ART: Anti-retroviral Therapy; AZT: Azidothymidine; HAART: Highly Active Antiretroviral Drug; HBsAg: Hepatitis B Surface antigen; HBV: Hepatitis B virus; HCV: Hepatitis C Virus; HIV: Human immunodeficiency virus; MACS: Multi-center AIDS Cohort Study; RNA: Ribonucleic Acid; TTl: transfusion-transmissible infections

\section{Acknowledgements}

We would like to thank all participants of this research, University of Gondar Hospital, Department of Blood Bank staffs, staffs of Department of Medical Microbiology, School of Biomedical and Laboratory Science, College of Medicine and Health Sciences for their contribution in the maturation and the success of this research.

\section{Funding}

There was no funding of the research. 


\section{Availability of data and materials}

All data generated or analyzed during this study are included in this article. Data that support the findings of this study are also available from the corresponding author upon reasonable request.

\section{Authors' contributions}

AT: Research idea, data collection, analysis, interpretation, manuscript writes up and review. FM: Conception of research idea, study design, data collection, analysis and interpretation, manuscript writes up and reviews. TE: data collection, qualitative and quantitative data analysis. All authors read and approved the final manuscript

\section{Ethics approval and consent to participate}

Ethical clearance was obtained from the University of Gondar ethical review committee. Written permission was obtained from the University of Gondar Compressive Specialized Hospital. The objectives of the study were explained to the heads of the health facilities and health care providers who worked at the blood bank department and clarification was given before starting data collection from the registrations and clients cards. To keep confidentiality of information from participants records, no personal identifiers were recorded in the client information extraction pre-designed form and data secured from participant records were not be available to anyone except for the main investigator.

\section{Consent for publication}

Not applicable.

\section{Competing interests}

The Authors declare that they don't have competing interests.

\section{Publisher's Note}

Springer Nature remains neutral with regard to jurisdictional claims in published maps and institutional affiliations.

\section{Author details}

${ }^{1}$ Department of Medical Microbiology, School of Biomedical and Laboratory Sciences, College of Medicine and Health Sciences, University of Gondar, P O.box: 196, Gondar, Ethiopia. ${ }^{2}$ Department of Medical Laboratory Sciences, School of Health Sciences, College of Medicine and Health Sciences, Bahir Dar University, Bahir Dar, Ethiopia.

Received: 18 December 2018 Accepted: 3 April 2019

Published online: 08 May 2019

\section{References}

1. UNAIDS. Report on the global AIDS epidemic. Geneva: Joint United Nations program on HIV/AIDS; 2002.

2. Sumbu BMM, Longo-Mbenza B, Ahuka-Mundeke S, Muwonga JM, MvumbiLelo G, Maphana HM, Kayembe DNN, Kalumbu FM. Association between the viruses of the acquired immunodeficiency syndrome and the hepatitis $C$ virus among young blood donors in Kinshasa: retrospective analysis of 10 years. Transfus Clin Biol. 2018;25(1):26-34.

3. Joan CM and David O (2000). Tumer viruses. In: Samuel B. $\left(4^{\text {th }}\right)$. Medical Microbiology. Texas: Calveston, 1021-10422.

4. Drosten C, Nippraschk T, Manegold C, Meisel H, Brixner V, Roth WK Apedjinov A, Gunther S. Prevalence of hepatitis B virus DNA in anti-HBC positive /HBsAg- negative sera correlates with HCV but not HIV serostatus. J ClinVirol. 2004;29:59-68.

5. Geo FB, Karen CC, Janet SB, Strephen AM (2007). Medical Microbiology; Virology $\left(24^{\text {th) }}\right.$.USA. McGraw Hill. 466-485.

6. Finlayson MDC, Hayes PC, Simpson KJ. Diseases of the liver and biliary system: hepatitis. In: Haslett C, Chilvers ER, Hunter JAA, editors. Davidson's principles and practice of medicine. London: Churchill Living stone: 1999. p. 706-15.

7. Sumbu BMM, Longo-Mbenza B, Nganga-Nkanga M, Masidi JM, NzongolaNkasu DK, Ferdinand MK, et al. Seroprevalence of Hepatitis C Virus in Donors Blood at the University Clinics of Kinshasa: 2005-2006 and 20082013. J Innov Res Health Sci. Biotechnol. 2016;1(4):216-24.

8. WHO. Hepatitis C: global prevalence. WklyEpidemiol Rec. 1999;74:421-8.
9. Raza SA, Clifford GM, Franceschi S. Worldwide variation in the relative importance of hepatitis B and hepatitis C viruses in hepatocellular carcinoma: a systematic review. Br J Cancer. 2007;96(7):1127-1134.

10. Osaro E, Charles AT. The challenges of meeting the blood transfusion requirements in Sub-Saharan Africa: the need for the development of alternatives to allogenic blood. J Blood Med. 2011;2(1):7-21.

11. Ashish CS, Prakash G, Bishnu RT, Manital R. Transfusion-transmissible infections among blood donors in Kathmandu, Nepal. J Infect DevCtries. 2009;3(10):794-7.

12. Mbanya DN, Tayou C. Blood safety begins with safe donations: update among blood donors in Yaounde, Cameroon. Transfus Med. 2005;15:395-9.

13. Mecky IM, Pius MM, Eligius FL. Seroprevalence of human immunodeficiency virus, hepatitis B and C viruses and syphilis infections among blood donors at the Muhimbili National Hospital in Dar Es Salaam, Tanzania. BMC Public Health. 2006;6:21. https://doi.org/10.1186/1471-2458-6-21.

14. Malak ME. Prevalance of HBV, HCV, HIV-I and II and HTLV-I/II among blood donors in a teaching hospital in the central region of Saudi Arabia. Saudi Med J. 2004:25(1):26-33.

15. Gelaw B, Mengitsu Y. The prevalence of HBV, HCV and malaria parasites among blood donor in Amhara and Tigray regional states. Ethiop J Health Dev. 2008;22(1):3-7.

16. Tessema B, Yismaw G, Kassu A, Amsalu A Mulu A (2010), Frank E, Ulrich S. The seroprevalence of HIV, HBV, HCV and syphilis infection among blood donors at University of Gondar Hospital. BMC Infect Dis .10:111.

17. Hassan A, Muktar HM, Mamman Al, Ahmed AJ. The incidence of HIV among blood donors in Kaduna, Nigeria. Afr Health Sci. 2008:8(1):60.

18. Ramos JM, Reyes F, Tesfamariam A. Seroprevalence of human immunodeficiency virus among blood donors in a rural Ethiopian hospital. Trop Dr. 2008:38(3):182-3.

19. Charles ER, Fanjasoa R, Maherisoa R, Vaomalala R, Richter R, Rindrar MRA Dominique R, Voahanngy A, Vincent $R$, Jean L, Leon PR. The Seroprevalence Hepatitis $C$ and associated risk factors in urban area of Antananarivo, Madagascar. BMC Infect Dis. 2008;8:25. https://doi.org/10. 1186/1471-2334-8-25.

20. Mohammad F, Masroor A, Gulzar A, Muhammad AK, Ghulam MD. Hepatitis $B, C$ and HIV:sero-prevalence of infection in blood donors. Professional Med J. 2006;13(4):632-6.

21. Forbi JC, Gabadi S, Alabi R, Iperepolu HO, Pam CR, Entonu PE, Agwale SM. The role of triple infection with hepatitis $B$ virus, hepatitis $C$ virus, and human immunodeficiency virus (HIV) type-1 on CD4+ lymphocyte levels in the highly HIV infected population of North-Central Nigeria. Memlnst Oswaldo Cruz. 2007:102(4):535-7.

22. Alphonsine KM, Marie Jeanne LK, Euloge E, Liliane SD, Daniel Coulibaly NG, Patrick L, Mireille D. Hepatitis C virus infection in Abidjan cote d Ivoire: heterogeneity of genotypes. Sci Res Essay Vol. 2008;3(4):139-42.

23. Noubiap JN, Joko WY, Nansseu JR, Tene UG, Siaka C. Sero-epidemiology of human immunodeficiency virus, hepatitis $B$ and $C$ viruses, and syphilis infections among first-time blood donors in Ede'a, Cameroon International. $J$ Infect Dis. 2013;17:832-7

24. Stokx J, Gillet P, De Weggheleire A, Casas EC, Maendaenda R, Beulane AJ, Jani IV, Kidane S, Mosse CD, Jacobs J, Bottieau E. Seroprevalence of transfusion-transmissible infections and evaluation of the pre-donation screening performance at the provincial Hospital of Tete, Mozambique. BMC Infect Dis. 2011 Dec;11(1):141.

25. Dessie A, Abera B, Wale F. Seroprevalence of major blood-borne infections among blood donars at Felege Hiwot referral hospital, Northwest Ethiopia. Ethiop J Health Dev. 2007;21(1):68-9.

26. Motayo BO, Faneye AO, Udo UA, Olusola BA, Ezeani I, Ogiogwa JI. Seroprevalence of transfusion transmissible infections (TTI), in first time blood donors in Abeokuta, Nigeria. Afr Health Sci. 2015;15(1):19-24.

27. Buseri FI, Muhibi MA, Jeremiah ZA. Sero-epidemiology of transfusiontransmissible infectious diseases among blood donors in Osogbo, southWest Nigeria. Blood Transfus. 2009 Oct;7(4):293.

28. Acar A, Kemahli S, Altunay H, Kosan E, Oncul O, Gorenek L, Cavuslu S. HBV HCV and HIV seroprevalence among blood donors in Istanbul, Turkey: how effective are the changes in the national blood transfusion policies. Braz J Infect Dis. 2010 Jan 1:14(1):41-6.

29. Shrestha AC, Ghimire P, Tiwari BR, Rajkarnikar M. Transfusion-transmissible infections among blood donors in Kathmandu, Nepal. J Infect Dev Ctries. 2009;3(10):794-7. 
30. Khattak MF, Salamat N, Bhatti FA, Qureshi TZ. Seroprevalence of hepatitis B, C and HIV in blood donors in northern Pakistan. J Pak Med Assoc. 2002; 52(9):398-402.

31. Pahuja S, Sharma M, Baitha B, Jain M. Prevalence and trends of markers of hepatitis $C$ virus, hepatitis $B$ virus and human immunodeficiency virus in Delhi blood donors: a hospital based study. Jpn J Infect Dis. 2007;60(6):389.

32. Moniri R, Mosayebii Z, Mossavi GA. Seroprevalence of cytomegalovirus, hepatitis $B$, hepatitis $C$ and human immunodeficiency virus antibodies among volunteer blood donors. Iran J Public Health. 2004;33(4):38-42.

33. Dayan S, Tekin A, Tekin R, Dal T, Hoşoğlu S, Yazgan UC, Bekçibaşı M, Gül K. HBsAg, anti-HCV, anti-HIV $1 / 2$ and syphilis seroprevalence in healthy volunteer blood donors in southeastern Anatolia. J Infect Dev Ctries. 2013; 7(09):665-9.

34. Kochhar A, Singh K, Kochhar S, Duggal G, Choudhary S, Pandey S. A Study To Assess Trend In Seroprevalence Of Hepatitis B Virus Infection Among Blood Donors Of Southern Haryana, India. Internet J Pathol. 2012;13:2.

35. Asif N, Khokhar N, llahi F. Sero-prevalence of HBV, HCV, and HIV infection among voluntary non remunerated \& replacement donors in northern Pakistan. Pak J Med Sci. 2004;20(1):24-8.

36. Nagalo MB, Sanou M, Bisseye C, Kaboré MI, Nebie YK, Kienou K, Kiba A, Dahourou H, Ouattara S, Zongo JD, Simporé J. Seroprevalence of human immunodeficiency virus, hepatitis $B$ and $C$ viruses and syphilis among blood donors in Koudougou (Burkina Faso) in 2009. Blood Transfus. 2011 Oct;9(4):419.

37. Deressa T, Birhan W, Enawgaw B, Abebe M, Baynes HW, Desta M, Terefe B, Melku M. Proportion and predictors of transfusion-transmissible infections among blood donors in north Shewa zone, Central North Ethiopia. PloS one. 2018;13(3):e0194083.

38. Zaheer HA, Saeed U, Waheed Y, Karimi S, Waheed U. Prevalence and trends of hepatitis $B$, hepatitis $C$ and human immunodeficiency viruses among blood donors in Islamabad, Pakistan 2005-2013. J Blood Disorders Transf. 2014;5(217):2.

39. Mohammed Y. Bekele A. Seroprevalence of transfusion transmitted infection among blood donors at Jijiga blood bank, eastern Ethiopia: retrospective 4 years study. BMC Res Notes. 2016;9(1):129.

40. Irfan SM, Uddin J, Zaheer HA, Sultan S, Baig A. Trends in transfusion transmitted infections among replacement blood donors in Karachi. Pak Turk J Hematol. 2013;30(2):163.

41. Manzoor I, Hashmi NO, Daud SE, Ajmal SA, Fatima HI, Rasheed ZA, Syed SA. Seroprevalence of transfusion transmissible infections (TTIS) in blood donors. Biomedica. 2009;25(10):154-8.

42. Bhawani Y, Rao PR, Sudhakar V. Seroprevalence of transfusion transmissible infections among blood donors in a tertiary care hospital of Andhra Pradesh. Biol Med. 2010:2(4):45-8.

Ready to submit your research? Choose BMC and benefit from:

- fast, convenient online submission

- thorough peer review by experienced researchers in your field

- rapid publication on acceptance

- support for research data, including large and complex data types

- gold Open Access which fosters wider collaboration and increased citations

- maximum visibility for your research: over $100 \mathrm{M}$ website views per year

At $\mathrm{BMC}$, research is always in progress.

Learn more biomedcentral.com/submissions 